\title{
Faktor Risiko Terjadinya Ulkus Diabetikum pada Pasien Diabetes Mellitus yang Dirawat Jalan dan Inap di RSUP Dr. M. Djamil dan RSI Ibnu Sina Padang
}

\author{
Rizky Loviana Roza ${ }^{1}$, Rudy Afriant ${ }^{2}$, Zulkarnain Edward ${ }^{3}$
}

\begin{abstract}
Abstrak
Ulkus diabetikum adalah keadaan ditemukannya infeksi, tukak dan atau destruksi ke jaringan kulit yang paling dalam di kaki pada pasien Diabetes Mellitus (DM) akibat abnormalitas saraf dan gangguan pembuluh darah arteri perifer. Ulkus diabetikum dapat dicegah dengan melakukan intervensi sederhana sehingga kejadian angka amputasi dapat diturunkan hingga 80\%. Amputasi memberikan pengaruh besar terhadap seorang individu, tidak hanya dari segi kosmetik tapi juga kehilangan produktivitas, meningkatkan ketergantungan terhadap orang lain serta biaya mahal yang dikeluarkan untuk penyembuhan. Penelitian ini memberikan pengetahuan tentang faktor risiko terjadinya ulkus diabetikum agar angka mortalitas dan morbiditas dapat di kurangi. Jenis penelitian ini adalah retrospektif observasional dengan mengumpulkan data menggunakan wawancara, kuisoner, dan pemeriksaan fisik pada pasien diabetes mellitus yang di rawat jalan dan inap di RSUP DR. M. Djamil dan RSI Ibnu Sina Padang periode JanuariMaret 2014. Analisis data terhadap 6 variabel di dapatkan Jenis kelamin $(p=0,595$; OR=0,654) lama DM ( $p=1,000 ;$ OR $=1,158)$, neuropati $(p=0,411 ; O R=1,833)$, PAD $(p=0,004 ; O R)$, trauma $(p=0,02 ; O R=4)$, dan perawatan kaki $(p=1,000 ; O R=1,158)$. Berdasarkan uji statistik Chi-Square didapatkan 2 variabel yang memiliki hubungan bermakna dengan kejadian ulkus diabetikum yaitu PAD dan trauma. Sedangkan, hasil uji statistik regresi logistik ganda menyatakan bahwa lama $\mathrm{DM}$, neuropati, $\mathrm{PAD}$, riwayat trauma, dan perawatn kaki merupakan faktor risiko terjadinya ulkus diabetikum. PAD dan trauma adalah faktor yang paling berpengaruh.
\end{abstract}

Kata kunci: faktor risiko, DM, ulkus diabetikum

\section{Abstract}

Diabetic foot ulcer is defined as the presence of infection, ulceration and/or destruction of deep tissues associated with neurologic abnormalities and various degrees of peripheral arterial disease (PAD) in the lower limb on patients with diabetes. Foot ulceration is preventable, and relatively simple interventions can reduce amputations by up to $80 \%$. Amputation has a major impact on individual, not only in distorting body image, but also loss of productivity, increasing dependency, and expensive cost of treating foot ulcer. This study provides knowledge about risk factors for diabetic ulcers that mortality and morbidity can be reduced. This research is an observational retrospective by collecting data using interviews, questionnaires, and physical examination in patients with diabetes mellitus in outpatient and inpatient department of DR. M. Djamil and RSI Ibnu Sina Padang from January until March 2014. The result from the analyze data from 6 variable known gender $(p=0,595 ; O R=0,654)$, duration of $D M(p=1,000 ; O R=$ $1,158)$, neuropathy $(p=0,411 ; O R=1,833), P A D(p=0,004 ; O R=5,5)$, trauma $(p=0,02 ; O R=4)$, and foot care $(p=1,000$; $O R=1,158)$. Based on Chi-Square test statistic obtained two variables that have a significant relationship with the occurrence of diabetic ulcers is $P A D$ and trauma. Meanwhile, the results of multiple logistic regression statistical tests that the old DM, neuropathy, PAD, history of trauma, and foot care a risk factor for diabetic ulcers. PAD and trauma are the most influential.

Keywords: risk factor, DM, diabetic foot ulcer 
Affiliasi penulis : 1 . Pendidikan Dokter FK UNAND (Fakultas Kedokteran Universitas Andalas Padang), 2. Bagian Penyakit Dalam FK UNAND/RSUP Dr. M. Djamil Padang, 3. Bagian Biokimia FK UNAND

Korespondensi : Rizky Loviana Roza, E-mail: rizkylovi@gmail.com, Telp: 085263553668

\section{PENDAHULUAN}

Penyakit Diabetes Melitus (DM) merupakan gangguan metabolisme karbohidrat, lemak dan protein yang berhubungan dengan defisiensi relatif atau absolut sekresi insulin yang ditandai dengan hiperglikemia kronis yang disebabkan oleh faktor lingkungan dan keturunan. Penyakit DM ini merupakan salah satu ancaman utama bagi umat manusia pada abad 21 ini. Badan WHO memperkirakan, pada tahun 2000 jumlah pengidap penyakit DM yang berusia di atas 20 tahun berjumlah 150 juta orang dan dalam kurun waktu 25 tahun kemudian pada tahun 2025, jumlah itu akan meningkat menjadi 300 juta orang. ${ }^{1}$

Penyakit DM dibagi ats 2 tipe, yakni tipe dapat menyebabkan perubahan patofisiologi pada berbagai sistem organ seperti mata, ginjal, ekstremitas bawah. ${ }^{2}$ Salah satu akibat komplikasi kronik atau jangka panjang penyakit DM adalah ulkus diabetikum. Ulkus diabetikum disebabkan adanya tiga faktor yang sering disebut trias, yaitu: iskemik, neuropati dan infeksi. $^{3}$

Faktor risiko terjadi ulkus diabetikum pada penderita penyakit DM adalah:

a. Jenis kelamin

Laki-laki menjadi faktor predominan berhubungan dengan terjadinya ulkus. Menurut Prastica dkk pasien ulkus diabetikum yang diteliti di RSUD Dr. Saiful Anwar Malang adalah laki-laki $(56,3 \%)$

\section{b. Lama Penyakit Diabetes Melitus (DM)}

Lamanya durasi DM menyebabkan keadaan hiperglikemia yang lama. Keadaan hiperglikemia yang terus menerus menginisiasi terjadinya hiperglisolia yaitu keadaan sel yang kebanjiran glukosa. Hiperglosia kronik akan mengubah homeostasis biokimiawi sel tersebut yang kemudian berpotensi untuk terjadinya perubahan dasar terbentuknya komplikasi kronik DM. Seratus pasien penyakit DM dengan ulkus diabetikum, ditemukan $58 \%$ adalah pasien penyakit DM yang telah menderita penyakit DM lebih dari 10 tahun. Hasil analisis regression kepada semua pasien rawat jalan di klinik penyakit dalam Veteran Affairs, Washington menyimpulkan bahwa rerata lama pasien penyakit DM ulkus diabetikum sebanyak 162 orang adalah 11.40 tahun dengan RR $1.18(95 \% \mathrm{Cl})$.

\section{c. Neuropati}

Neuropati menyebabkan gangguan saraf motorik, sensorik dan otonom. Gangguan motorik menyebabkan atrofi otot, deformitas kaki, perubahan biomekanika kaki dan distribusi tekanan kaki terganggu sehingga menyebabkan kejadian ulkus meningkat. Gangguan sensorik disadari saat pasien mengeluhkan kaki kehilangan sensasi atau merasa kebas. Rasa kebas menyebabkan trauma yang terjadi pada pasien penyakit DM sering kali tidak diketahui. Gangguan otonom menyebabkan bagian kaki mengalami penurunan ekskresi keringat sehingga kulit kaki menjadi kering dan mudah terbentuk fissura. Saat terjadi mikrotrauma keadaan kaki yang mudah retak meningkatkan risiko terjadinya ulkus diabetikum. Menurut Boulton AJ pasien penyakit DM dengan neuropati meningkatkan risiko terjadinya ulkus diabetikum tujuh kali dibanding dengan pasien penyakit DM tidak neuropati.

\section{d. Peripheral Artery Disease}

Penyakit arteri perifer adalah penyakit penyumbatan arteri di ektremitas bawah yang disebakan oleh atherosklerosis. Gejala klinis yang sering ditemui pada pasien PAD adalah klaudikasio intermitten yang disebabkan oleh iskemia otot dan iskemia yang menimbulkan nyeri saat istirahat. Iskemia berat akan mencapai klimaks sebagai ulserasi dan gangren. Pemeriksaan sederhana yang dapat dilakukan untuk deteksi PAD adalah dengan menilai Ankle Brachial Indeks (ABI) yaitu pemeriksaan sistolik brachial tangan kiri dan kanan kemudian nilai sistolik yang paling tinggi dibandingkan dengan nilai sistolik yang paling tinggi di tungkai. Nilai normalnya dalah 0,9 - 1,3. Nilai dibawah 0,9 itu dindikasikan bawah pasien penderita DM memiliki penyakit arteri perifer. 


\section{e. Perawatan kaki}

Edukasi perawatan kaki harus diberikan secara rinci pada semua orang dengan ulkus maupun neuropati perifer atau peripheral Artery disease (PAD). Menurut penelitian Purwanti OK perawatan kaki terdiri dari perawatan perawatan kaki setiap hari, perawatan kaki reguler, mencegah injuri pada kaki, dan meningkatkan sirkulasi. ${ }^{1}$

\section{METODE}

Jenis penelitian ini adalah analitik observational yang menggunakan desain penelitian case control. Pengukuran dilakukan terhadap variabel terikat yaitu pasien ulkus diabetikum dan variabel bebas yaitu jenis kelamin, lama menderita penyakit DM, neuropati perifer, Peripheral Artery Deasease (PAD), perawatan kaki. Penelitian ini dilakukan di rawat jalan \& rawat inap RSUP M. Djamil Padang yang dilakukan hingga jumlah sampel terpenuhi.

Sampel yang digunakan dalam penelitian ini adalah pasien DM dengan ulkus diabetikum, sebagai populasi kasus, dan pasien DM yang tidak menderita uklus diabetikum, sebagai populasi kontrol, yang dirawat di RSUP DR. M. Djamil yang memenuhi kriteria inklusi dan ekslusi. Untuk kriteria Inklusi meliputi penderita penyakit DM dengan ulkus diabetikum dan tanpa uklus diabetikum yang dirawat jalan dan inap di RSUP M. Djamil, bersedia menjadi pasien, sedangkan kriteria Ekslusi adalah pasien yang mengalami penurunan kesadaran. Teknik pengambilan sampel yang digunakan pada penelitian ini adalah simple random sampling. Besar minimal sampel yang digunakan untuk pasien DM dengan ulkus diabetikum dan pasien DM tanpa ulkus diabetikum masing-masingnya adalah 27.

Langkah-langkah pengolahan data adalah pemeriksaan kelengkapan dan kejelasan data, pemberian kode pada setiap data variabel, memasukkan data dalam program SPSS, serta pemeriksaan kembali untuk memastikan bahwa data tersebut telah bersih dari kesalahan. Analisis data terdiri dari analisis bivariat dan multivariat. Pada analisis bivariat dicari hubungan antara dua variabel dengan menggunakan rumus chi square dan Analisis keeratan hubungan antara dua variabel tersebut dengan melihat nilai Odd Ratio (OR).
HASIL

Berdasarkan hasil penelitian tentang faKtor risiko ulkus diabetikum pada pasien DM yang dilakukan di RSUP Dr. M. Djamil dan RSI Ibnu Sina Padang didapatkan hasil pada tabel dibawah ini:

Tabel 1. Analisis Bivariat

\begin{tabular}{ccccccc}
\hline $\begin{array}{c}\text { Faktor } \\
\text { Risiko }\end{array}$ & \multicolumn{2}{c}{$\begin{array}{c}\text { DM dengan } \\
\text { ulkus }\end{array}$} & \multicolumn{2}{c}{$\begin{array}{c}\text { DM tanpa } \\
\text { ulkus }\end{array}$} & Total & Nilai p \\
\cline { 2 - 7 } & $\mathbf{f}$ & $\%$ & $\mathbf{f}$ & $\%$ & $\mathbf{f}$ & \\
\hline Lama DM & & & & & & \\
$<5$ tahun & 10 & 33,3 & 11 & 36,3 & 21 & 1,00 \\
$>5$ tahun & 20 & 63,7 & 19 & 66,7 & 39 & \\
Neuropati & & & & & & \\
Ada & 22 & 73,3 & 18 & 60 & 40 & 0,411 \\
Tidak & 8 & 26,7 & 12 & 40 & 20 & \\
PAD & & & & & & \\
Ada & 22 & 73,3 & 10 & 33,3 & 32 & 0,004 \\
Tidak & 8 & 26,7 & 20 & 66,7 & 28 & \\
Trauma & & & & & & \\
Ada & 20 & 66,7 & 10 & 33,3 & 30 & 0,02 \\
Tidak & 10 & 33,3 & 20 & 66,7 & 30 & \\
Perawatan kaki & & & & & \\
Rutin & 10 & 33,3 & 11 & 36,7 & 21 & 1,00 \\
Tidak & 20 & 66,7 & 19 & 63,3 & 39 & \\
\hline
\end{tabular}

Berdasarkan tabel 1 dapat disimpulkan bahwa faktor risiko yang paling berpengaruh terhadap kejadian ulkus diabetikum adalah PAD dan trauma.

Tabel 2. Hasil Pemodelan Awal Analisis Multivariat

\begin{tabular}{lllll}
\hline Variabel & $\mathrm{B}$ & $\mathrm{p}$ value & $\begin{array}{l}\text { Odds } \\
\text { Ratio/OR }\end{array}$ & $\mathrm{Cl} 95 \%$ \\
\hline Lama DM & 0,506 & 1,00 & 0,603 & $0,143-2,545$ \\
Neuropati & 0,63 & 0,411 & 1,827 & $0,442-7,547$ \\
PAD & 2,121 & $0,004^{*}$ & 8,343 & $2,179-31,948$ \\
Trauma & 1,953 & $0,020^{*}$ & 7,049 & $1,714-28,994$ \\
Perawatan kaki & 0,823 & 1,00 & 2,277 & $0,577-8,989$ \\
\hline
\end{tabular}

Berdasarkan tabel 2 dengan metode backward, dikeluarkan tahap demi tahap faktor risiko yang memiliki nilai $p$ value $<0,05$

Tabel 3. Hasil Pemodelan Akhir Faktor-faktor Risiko Terjadi Ulkus Diabetikum pada Pasien DM

\begin{tabular}{llllll}
\hline No & Variabel & $\mathrm{B}$ & $\mathrm{p}$ value & Odds Ratio/OR & $\mathrm{Cl} 95 \%$ \\
\hline 1 & PAD & 2,017 & 0,02 & 7,518 & $2,091-27,026$ \\
2 & Trauma & 1,740 & 0,07 & 5,698 & $1,593-20,384$ \\
\hline
\end{tabular}


Berdasarkan tabel 3 faktor yang paling berpengaruh adalah PAD dan trauma.

\section{PEMBAHASAN}

Berdasarkan hasil penelitian ini pasien yang mengalami ulkus lebih banyak diderita oleh perempuan, dimana pasien DM wanita yang mengalami ulku sebanyak $67 \%$. Hasil ini berbeda dari penelitian yang dilakukan oleh Tentolouris menunjukan bahwa laki-laki lebih banyak terkena ulkus di banding wanita. ${ }^{11}$

Berdasarkan kepustakaan, pasien ulkus lebih banyak didominasi oleh laki-laki. Perbedaan hasil ini dapat disebabkan oleh karaktareristik pasien perempuan di penelitian ini yaitu pasien perempuan yang memiliki rata-rata usia diatas 55 tahun. Usia ini merupakan usia menuju dewasa tua dan dikaitkan pada usia tersebut perempuan mulai memasuki masa menopause yang menyebabkan terjadinya penurunan hormon estrogen. Estrogen merupakan faktor protektif terhadap penyakit athresklerosis sehingga perempuan pada usia tersebut lebih rentan terkena ulkus diabetikum. Faktor rata-rata usia pasien DM pada penelitian ini menyebabkan pasien ulkus lebih banyak didapatkan pada perempuan dibandingkan laki-laki.

Hasil analisis data menunjukan tidak ada hubungan signifikan antara lama DM dengan kejadian ulkus diabetikum ( $p=0.491$ atau $p>0.05)$. Namun, presentase menyatakan bahwa pasien dengan ulkus lebih banyak terjadi pada pasien dengan lama $D M \geq 5$ tahun. Hal ini sesuai dengan penelitian Boyko yang mendapatkan bahwa pasien ulkus rata-rata mengalami DM selama 11.4 tahun. ${ }^{12}$ Menurut kepustakaan lama DM $\geq 5$ tahun merupakan faktor risiko terjadiya ulkus diabetikum karena neuropati cenderung terjadi sekitar 5 tahun lebih atau sama dengan setelah menderita DM. ${ }^{13}$ Hal tersebut dikarenakan semakin lama menderita DM maka kemungkinan terjadinya hiperglikemia kronik semakin besar. Hiperglikemia kronik dapat menyebabkan komplikasi DM yaitu retinopati, nefropati, PJK, dan ulkus dabetikum.

Persentase pasien ulkus yang mengalami neuropati adalah sebanyak $73 \%$ sedangkan yang tidak ulkus mengalami neuropati sebanyak 60\%. Hasil analisis data menunjukan tidak ada hubungan yang signifikan antara neuropati dengan kejadian ulkus $(p=0.405$ atau $p>0.05)$. Namun nilai $O R>1 \quad(O R=1.827)$ pada penelitian ini menunjukan bahwa neuropati merupakan faktor risiko terjadinya ulkus diabetikum. Pada penelitian ini didapatkan hasil yang tidak signifikan disebabkan karena untuk mendapatkan hasil yang berhubungan pada analisis data, jumlah pasien yang tidak neuropati pada pasien non ulkus harus lebih banyak daripada pasien yang neuropati. Pada penelitian lebih banyak pasien yang mengalami neuropati dibandingkan tidak neuropati. Menurut penelitian Reiber hampir 45-60\% pasien ulkus diabetikum mengalami neuropati. ${ }^{1}$ Neuropati yang paling sering menyebabkan ulkus pada pasien DM adalah neuropati sensorik. ${ }^{13}$ Kehilangan sensasi di kaki menyebabkan pasien tidak dapat mengetahui dan merasakan apabila terjadi luka di kaki. Luka yang terlambat diketahui ini menyebabkan terjadi ulkus diabetikum. ${ }^{1}$ Neuropati lainnya adalah neuropati motorik yang menyebabkan deformitas pada kaki dan bagian yang mengalami deformitas sering menjadi tempat terjadi ulkus berulang setelah ulkus sebelumnya sembuh. Selanjutnya neuropati otonom sering menyebabkan kulit pasien ulkus kering dan retak. Keadaan tersebut merupakan media tempat mudahnya berkembangbiak bakteri. Menurut kepustakaan neuropati merupakan faktor risiko terjadinya ulkus diabetikum. ${ }^{1}$

Hasil penelitian ini menunjukan bahwa PAD berhubungan dengan kejadian ulkus diabetikum. Hal ini terlihat dengan nilai $p=0,002$ dan nilai $O R=5,5$ $(\mathrm{Cl}=1,813-16,681)$. Hasil ini selaras dengan penelitian Mayfield dkk yang menunjukan bahwa PAD merupakan salah satu faktor yang menyebabkan terjadinya ulkus diabetikum. ${ }^{1}$ Iskemia yang terjadi menyebabkan kaki merah dan kering sering bersamaan dengan neuropati, sehingga menyebabkan peningkatan risiko terjadinya ulkus diabetikum. Aliran darah yang tidak lancar di kaki menyebabkan luka sukar sembuh dan menyebabkan risiko untuk amputasi lebih besar. Selain itu, oksigenisasi yang kurang ke tempat yang terkena luka sehingga antibiotik sulit untuk didistribusikan kedaerah tersebut menyebabkan bakteri sangat cepat sekali berkembang biak. ${ }^{3}$ Menurut ADA, PAD dapat dideteksi dini dengan melakukan pemeriksaan $\mathrm{ABI}$ (Ankle Brachial Index) 
pada pasien DM pada usia yang lebih dari 40 tahun. Pemeriksaan $\mathrm{ABI}$ lebih dini pada pasien DM usia lebih 40 tahun dapat mengantisipasi komplikasi PAD ini.

Hasil penelitian ini menunjukan hubungan yang signifikan antara trauma degan kejadian ulkus diabetikum $(p=0.07)$. Terdapatnya deformitas pada kaki menyebabkan terjadinya penekanan yang berulang terhadap bagian tersebut saat menggunakan sepatu, sehingga pergesekan terus menerus menyebabkan bagian tersebut mudah terkena trauma. Penekanan terus menerus pada telapak kaki saat berjalan juga dapat menyebabkan pasien ulkus kaki mudah sekali mengalami trauma. ${ }^{1}$ Faktor trauma pada pasien ulkus diabetikum bukan merupakan faktor tunggal terjadinya ulkus diabetikum, tetapi bersamaan dengan neuropati dan PAD. Trauma menyebabkan ulkus diabetikum yang sulit disembuhkan dan menjadi beban fisik dan mental bagi pasien yang menderitanya. ${ }^{2}$

Analisis bivariat yang dilakukan menunjukan hubungan yang tidak bermakna antara perawatan kaki dengan kejadian ulkus diabetikum $(p=0.241)$. Namun nilai $O R>1$ menunjukan perawatan kaki merupakan faktor risiko terjadinya ulkus diabetikum. Hal ini sejalan dengan penelitian yang dilakukan Hastuti bahwa perawatan kaki tidak teratur merupakan faktor risiko terjadinya ulkus diabetikum. ${ }^{3}$

Berdasarkan penelitian lainnya, lima dari enam pasien yang mengalami ulkus setelah di lakukan program intensif perawatan kaki tidak ada responden yang berkembang terjadi ulkus berulang. ${ }^{1}$ Berdasarkan penelitian dari 352 responden, mayoritas $78,4 \%$ pasien memililiki pengetahuan yang kurang tentang perawatan kaki. ${ }^{1}$

Hasil penelitian ini tidak signifikan disebabkan data yang peneliti dapatkan kurang mewakili gambaran tentang perawatan rutin yang dilakukan oleh pasien ulkus diabetikum. Dari hasil penelitian ini, pasien ulkus dan non ulkus sangat didominasi dengan perawatan kaki yang tidak rutin. Pada hasil analisis multivariat menunjukan perawatan kaki merupakan faktor risio terjadinya ulkus diabetikum. Berdasarkan kepustakaan, perawatan kaki merupakan faktor risiko terjadinya ulkus diabetikum.

\section{KESIMPULAN}

Faktor risiko terjadinya ulkus diabetikum adalah lama DM, neuropati, perawatan kaki, PAD dan trauma. Faktor risiko yang paling berpengaruh adalah PAD dan trauma.

\section{DAFTAR PUSTAKA}

1. Suyono $S$. Diabetes Mellitus di Indonesia. Dalam:Sudoyo A, Setiyohadi B, Alwi I, Simadibrata $\mathrm{KM}$, Setiati S, editor (penyunting). Buku Ajar IImu Penyakit Dalam. Jilid III. Edisi ke-5. Jakarta: Interna Publishing; 2009.

2. Clare-salzier MJ, Crawford JM, Kumar V. Pankreas. Dalam: Kumar V, Cotran RS, Robbins SL, editor (penyunting). Buku Ajar Patologi. Edisi ke-7. Jakarta: EGC; 2007.

3. Hastuti RT. Faktor-faktor risiko ulkus diabetika pada Penderita Diabetes Mellitus (Tesis). Semarang: Universitas Diponegoro. (Unpublised); 2008.

4. Prastica VA, Chuluq AC, Soemardini. Perbedaan Angka Kejadian Ulkus Diabetikum Pada Pasien Diabetes Melittus dengan dan Tanpa Hipertensi di RSUD Dr. Saiful Anwar Malang (skripsi). Malang: Fakultas Kedokteran, Universitas Brawijaya. (Published); 2013.

5. Waspadji S. Komplikasi Kronik Diabetes: Mekanisme Terjadinya, Diagnosis dan Strategi pengelolaan. Dalam: Sudoyo A, Setiyohadi B, Alwi I, Simadibrata KM, Setiati $S$, editor (penyunting). Buku Ajar IImu Penyakit Dalam. Jilid III. Edisi ke-5. Jakarta: Interna Publishing; 2009.

6. Ali SM, Sheikh T, Mumtaz S, Hydrie MZ. Diabetic Foot Ulcer-Prospective Study. The Journal of the Pakistan Medical Association. 2001; 51 (2): 78-81.

7. Khanolkar MP, Bain SC, Stephens JW, 2008. The diabetic foot. The Oxford Journal. 101: 685-95.

8. Boulton AJ. The diabetic foot : from art to science. Diabetologia. 2004; 47: 1343-53.

9. Denekamp LJ, Folcarelli PH. Penyakit Pembuluh Darah. Dalam Price SA, Wilson LM, 2006. Patofisiologi. Volume II. Edisi VI. Jakarta: EGC; 2006.

10. Purwanti OK. Analisis Faktor-Faktor Risiko Terjadi 
Ulkus Kaki Pada pasien Diabetes Mellitus Di RSUD

DR. Moewardi. Tesis Magister, Fakultas IImu Keperawatan, Universitas Indonesia, Jakarta. (Published);2013.

11. Tentolouris N. Introduction. Dalam : Katsilambros N, Dounis E, Makrilakis K, Tentolouris N, Tsapogas $\mathrm{P}$, Atlas of the Diabetic Foot. Edisi II. Singapore: Blackwell Publishing;2010.

12. Boyko EJ, Ahroni JH, Stensel V, Forsberg RC, Davignon DR, Smith DG. A Prospective Study of Risk Factors for Diabetic Foot Ulcer. Diabetes Care. 2004; 22(7): 1036-42.

13. Frykberg RG, Diabetic Foot Disorders A Clinical Practice Guidline. The Journal of Foot an Ankle.2006;5(5).

14. Reiber GE, Vileikyte I, Boyko EJ, Aguila MD, Smith DG. Lavery LA, Boulton AJM. Causal pathways for Incident lower extremity ulcer in Patients with Diabetes From two settings. Diabetes Care. 22;1999.

15. Schteingart DE. Pankreas: Metabolisme Glukosa dan Diabetes Melitus. Dalam Price SA, Wilson LM,
2006. Patofisiologi. Volume II. Edisi VI. Jakarta: EGC; 2006.

16. Desalu OO, Salawu FK, Jimoh AK, Adekoya AO, Busari AO, Olokoba AO. Diabetic foot care: Reported Knowledge and practice among patients attending three Tertiary Hospital in Nigeria. Ghana Medical Journal. 45;2011.

17. Flynn MD, Tooke JE. Aetiology of Diabetic Foot Ulceration : A Role For The Microcirculation. Diabetic Med.1992 : 8:320-9.

18. Myfield JA, Reiber GE, Sandres LJ, Janisse D, Pogach LM. Preventive Foot Care in people With Diabetes. Diabetes Care.1998; 21(21): 2161-77.

19. Mueller MJ, Hatings M, Commean PK, Smith KE, Pilgram TK, Robertson D, Johson J. Forefoot structural predictors of plantar pressures during walking in people with diabetes and peripheral neuropathy. Journal Biomech.2003; 36: 1009-17.

20. Pham H, Amstrong DG, Haervey C, Harkless LB, Giurini JM, Veves A. Screening techniques to indentify people at high risk for diabetic foot ulceration : a prospective multicenter trial. Diabetes Care. 2000; 23: 606-11. 